\title{
Comparison of the concentration of leptin between obese women and obese men with essential hypertension
}

\author{
Justyna Widecka', Katarzyna Widecka-Ostrowska', Joanna Ziemak', Anna Brzeska', Jacek Głowala', \\ Tomasz Miazgowski', Krystyna Widecka ${ }^{1}$
}

${ }^{1}$ Department of Hypertension and Internal Diseases, Pomeranian Medical University in Szczecin.

${ }^{2}$ Department of Cardiology, Pomeranian Medical University in Szczecin

\begin{abstract}
Background. The main determinants of the level of leptin in human plasma are the fat mass and sex. In recent literature many papers have been published indicating the participation of leptin in the pathogenesis of essential hypertension. The aim of this study was to compare serum levels of leptin and evaluate its importance in the pathophysiology of hypertension in obese men and women.

Material and methods. The study was conducted in a group of a total of 52 obese individuals (26 women and 26 men) with newly diagnosed essential hypertension. The study protocol included blood sample collection for the measurements of biochemical parameters and hormone levels. Biochemical assays were performed using routine methods. Serum insulin was determined by immunoradiometric assay (IRMA). The index of insulin resistance (IR) was calculated using HOMA. Leptin, plasma renin activity (PRA) and plasma aldosterone concentration were determined by radioimmunoassay (RIA).

Results. No significant differences were found between women and men in terms of age, BMI, blood pressure, total cholesterol, LDL and fasting glucose. Men had slightly but significantly higher waist circumference. The group of women had significantly higher levels of leptin, insulin and insulin resistance, and a higher PRA and aldosterone levels than males. In the group studied, leptin significantly positively correlated with blood pressure, as well as with the concentration of aldosterone and renin both in women and in men. There was no similar relationship between leptin and insulin and the insulin resistance index.
\end{abstract}

Conclusions.

1. Women with obesity and hypertension have higher levels of leptin than obese men with hypertension.

2. Reported correlations between plasma leptin concentration and blood pressure suggest that it is directly or indirectly involved in the pathophysiology of hypertension in obese individuals regardless of gender.

key words: leptin, arterial hypertension, obesity, sex

Arterial Hypertens. 2016, vol. 20, no. 3, pages: 108-112

DOI: $10.5603 / A H .2016 .0016$

\section{Introduction}

The discovery of leptin in 1994 and the recognition of its effect on the cardiovascular system resulted in

Address for correspondence: prof. dr hab. n. med. Krystyna Widecka Klinika Hipertensjologii i Chorób Wewnętrznych,

Pomorski Uniwersytet Medyczny

ul. Unii Lubelskiej 1, 71-252 Szczecin

tel.: (091) 425-35-50; fax: (091) 425-35-52

e-mail: widecka@o2.pl

VM Copyright (C) 2016 Via Medica, ISSN 2449-6170 an increase in research activity in the role of this hormone in the pathogenesis of cardiovascular diseases. In recent literature many papers have been published indicating the participation of leptin in the pathogenesis of essential hypertension [1-5].

So far the results have not enabled clear identification of the mechanisms by which leptin would lead to an increase in blood pressure. Most researchers suggest that the main link between high blood pressure and leptin is the stimulation of the activity of the sympa- 
thetic nervous system $[6,7]$. It was also shown that leptin is involved in the regulation of blood pressure due to its direct diuretic and natriuretic activity $[8,9]$.

The current literature suggests that obese people develop leptin resistance. This phenomenon leads to the state of its relative deficiency, despite high concentrations of plasma leptin [10]. The literature emphasizes the importance of leptin resistance in the pathogenesis of hypertension in obese people.

The main determinants of the level of leptin in human plasma are the fat mass and sex [11-13]. Sexual dimorphism in plasma concentrations of leptin has been documented. It has been shown that premenopausal women have higher adiposity-adjusted leptin levels than women after the menopause and that both of these groups are characterized by a higher concentration of the hormone than men. The observed sex differences are attributed to the guiding role of oestrogen and the damping androgen effect on leptin secretion [14]. However, not all researchers agree with these suggestions $[15,16]$.

Due to the very heterogeneous criteria for the selection of patients for published studies (BMI, sex, severity of hypertension, drugs), the results are often divergent, and difficult to interpret and compare.

The aim of this study was to compare plasma levels of leptin and evaluate its importance in the pathophysiology of hypertension in obese men and women.

\section{Material and methods}

The study was conducted in a group of a total of 52 obese individuals ( 26 women and 26 men) with newly diagnosed essential hypertension grade 1 or 2 according to Polish Society of Hypertension (PTNT) [17]. The diagnosis of hypertension was determined to give based on the measurements during two separate visits in an outpatient setting. Measurements were made by mercury manometer, with at least 15 minutes of rest in a sitting position, at intervals of at least 2 minutes. At each visit blood pressure measurements were taken three times. The resultant average value of all measurements was taken for further calculation, in accordance with the recommendation of the PTNT [17]. The study included patients that met the criteria of essential hypertension, after exclusion of secondary hypertension based on routine clinical, laboratory and radiological examinations [18].

The study protocol was approved by the Bioethics Committee of the Pomeranian Medical University in Szczecin.

The study protocol included blood sample collection for the measurements of biochemical parameters and hormone levels. Blood samples were collected at 8 in the morning on an empty stomach, after at least 8 hours of rest at night.

Biochemical assays were performed using routine methods included the parameters of lipid metabolism and blood glucose.

Serum insulin was determined by immunoradiometric assay (IRMA). The index of insulin resistance (IR) was calculated using HOMA (glucose concentration $[\mathrm{mml} / \mathrm{l}] \mathrm{x}$ fasting insulin levels [uIU/ml]: 22.5).

Plasma leptin concentration was determined by radioimmunoassay (RIA). Plasma renin activity (PRA) and plasma aldosterone levels (ALDO) were determined using RIA.

Statistical analysis was performed using Statistica (StatSoft, Inc., USA).

The normality of the distribution was tested with the Shapiro-Wilk test. Independent variables with normal distribution were examined using t-tests, with evaluation of homogeneity of variance. Non-normally distributed variables were examined by non-parametric tests. Differences in the values of these variables between subgroups were evaluated using the non-parametric Kruskal-Wallis test and/or the Mann-Whitney U test.

For the assessment of the correlation between the parameters, Spearman's rank correlation test was used. Values of $\mathrm{p}<0.05$ were taken as statistically significant.

\section{Results}

Table I provides a comparison of mean values of evaluated clinical, biochemical and hormonal parameters in men and women.

No significant differences were found between in terms of age, BMI, blood pressure, total cholesterol, LDL and fasting glucose. Men had slightly but significantly higher waist circumference. The group of women had significantly higher levels of leptin, insulin and insulin resistance, and a higher plasma renin activity and aldosterone levels than males.

Table II presents correlations between leptin and evaluated parameters in the group of women.

In the group of obese women with hypertension, plasma leptin levels significantly positively correlated with BMI, blood pressure, and the concentration of aldosterone and renin. There were no similar relationships between leptin and insulin and the insulin resistance index.

Table III presents correlations between leptin and the evaluated parameters in the group of men.

In obese men with hypertension, as well as in women, plasma leptin levels correlated positively with the parameters of blood pressure and the concentration of 
Table I. Comparison of mean ( \pm SD) values of studied parameters between obese women and obese men with arterial hypertension

\begin{tabular}{|c|c|c|c|}
\hline Variable & $\begin{array}{l}\text { Women } \\
n=26\end{array}$ & $\begin{array}{c}\text { Men } \\
n=26\end{array}$ & p-value \\
\hline Age (years) & $35.5 \pm 5.1$ & $32.6 \pm 5.3$ & ns \\
\hline Body mass index $\left[\mathrm{kg} / \mathrm{m}^{2}\right]$ & $33.1 \pm 2.4$ & $32.0 \pm 1.7$ & ns \\
\hline Waist circumference [cm] & $100.1 \pm 11.5$ & $104.9 \pm 3.2$ & $<0.001$ \\
\hline Systolic blood pressure [mm Hg] & $165.8 \pm 13.1$ & $161.5 \pm 14.2$ & ns \\
\hline Diastolic blood pressure [mm Hg] & $100.8 \pm 4.2$ & $99.5 \pm 3.4$ & ns \\
\hline Mean blood pressure [mm Hg] & $122.5 \pm 6.6$ & $121.7 \pm 11.7$ & ns \\
\hline Heart rate [f/min] & $75.7 \pm 8.9$ & $68.3 \pm 5.2$ & $<0.05$ \\
\hline Total cholesterol [mg/dl] & $238.2 \pm 23.5$ & $238.4 \pm 13.5$ & ns \\
\hline $\mathrm{HDL}[\mathrm{mg} / \mathrm{dl}]$ & $42.9 \pm 2.9$ & $32.2 \pm 3.8$ & $<0.001$ \\
\hline LDL [mg/dl] & $162.3 \pm 23.7$ & $170.0 \pm 15.7$ & ns \\
\hline Triglycerides [mg/dl] & $181.0 \pm 30.6$ & $186.6 \pm 17.5$ & $<0.025$ \\
\hline Fasting glucose[mg/dl] & $89.8 \pm 7.1$ & $89.2 \pm 6.5$ & ns \\
\hline Fasting insulin [ulU/ml] & $12.0 \pm 6.9$ & $7.4 \pm 3.6$ & $<0.05$ \\
\hline IR & $2.61 \pm 1.43$ & $1.61 \pm 0.79$ & $<0.05$ \\
\hline Leptin [ng/ml] & $25.1 \pm 8.7$ & $9.3 \pm 4.9$ & $<0.001$ \\
\hline Plasma renin activity [ng/Al/ml/h] & $3.22 \pm 0.72$ & $1.62 \pm 0.64$ & $<0.001$ \\
\hline Aldosterone [pg/ml] & $257.4 \pm 57.9$ & $137.9 \pm 44.9$ & $<0.001$ \\
\hline
\end{tabular}

HDL — high density lipoprotein, LDL — density lipoprotein, IR — insulin resistance

Table II. Correlations between leptin and other variables in obese women with arterial hypertension

\begin{tabular}{|l|l|c|c|}
\hline Variable & Variables & $\mathbf{R}$ & p-value \\
\hline \multirow{5}{*}{ Leptin } & Body mass index & 0.54 & $<0.005$ \\
\cline { 2 - 4 } & Systolic blood pressure & 0.85 & $<0.001$ \\
\cline { 2 - 4 } & Diastolic blood pressure & 0.77 & $<0.001$ \\
\cline { 2 - 4 } & Mean blood pressure & 0.92 & $<0.001$ \\
\cline { 2 - 4 } & Fasting insulin & 0.30 & ns \\
\cline { 2 - 4 } & Insulin Resistance & 0.32 & $<0.001$ \\
\cline { 2 - 4 } & Plasma renin activity & 0.86 & $<0.001$ \\
\cline { 2 - 4 } & Aldosterone & 0.87 & $<$ \\
\hline
\end{tabular}

$R$ refers to the Spearman rank correlation coefficient

Table III. Correlations between leptin and other variables in obese men with arterial hypertension

\begin{tabular}{|l|l|c|c|}
\hline Variable & Variables & $\mathbf{R}$ & $\mathrm{p}$-value \\
\hline \multirow{5}{*}{ Leptin } & Body mass index & 0.12 & $\mathrm{~ns}$ \\
\cline { 2 - 4 } & Systolic blood pressure & 0.60 & $<0.001$ \\
\cline { 2 - 4 } & Diastolic blood pressure & 0.48 & $<0.05$ \\
\cline { 2 - 4 } & Mean blood pressure & 0.49 & $<0.05$ \\
\cline { 2 - 4 } & Fasting insulin & 0.22 & $\mathrm{~ns}$ \\
\cline { 2 - 4 } & Insulin Resistance & 0.22 & $\mathrm{~ns}$ \\
\cline { 2 - 4 } & Plasma renin activity & 0.84 & $<0.001$ \\
\cline { 2 - 4 } & Aldosterone & 0.87 & $<0.001$ \\
\hline
\end{tabular}


aldosterone and renin. There were no similar relationships between BMI and leptin, and insulin and the insulin resistance index.

\section{Discussion}

The present study confirmed previously suggested dependence of the concentrations of leptin on patients' gender $[12,19]$. Women with obesity and hypertension had higher leptin levels than the same group of men. As demonstrated by in vivo studies, oestrogens may be responsible for these differences [14]. Mannucci et al. confirmed the regulatory effect of oestrogens on leptin secretion, indicating a significantly lower concentration of leptin in the early stage of the cycle, when the oestrogen level is reduced [20]. However, the mechanism of sexual dimorphism of leptin remains unclear.

In the present study, there is a statistically significant positive correlation between leptin and blood pressure both in women and in men with obesity. Our results indicate that hyperleptinaemia may be an important link between obesity and hypertension. Leptin, a peptide hormone secreted by adipocytes in proportion to body fat mass, crosses the blood-brain barrier via a saturable transport system to activate its receptors in various regions of the central nervous system, especially in the hypothalamus and brainstem, to reduce appetite and increase energy expenditure [21].

Within physiological concentrations of leptin, its effect on the cardiovascular system results in the fall in blood pressure, whereas in conditions of chronic hyperleptinaemia accompanying obesity the pressor effect is dominating [22-24]. On the basis of the authors' own observations, it can be assumed that leptin affects blood pressure, not only through its receptors, but also through indirect routes, e.g. through the renin-angiotensin-aldosterone system.

This explanation is supported by our study [25], which showed positive correlations of leptin concentration with aldosterone and renin. In the current literature, it has been demonstrated that leptin is a new direct regulator of adrenal aldosterone synthase expression and an inducer of aldosterone production. These data demonstrate that leptin induces hypertension and endothelial dysfunction via aldosterone-dependent mechanisms in female mice and suggest that obesity leads to cardiovascular disease via sex-specific mechanisms [25].

In the present study, both in women and men, there was no correlation between leptin and insulin or between leptin and the insulin resistance index. The literature reports on the subject are inconclusive. Similarly to the results from our study, Carantoni et al. showed no relationship between leptin and insulin concentrations and insulin resistance in the population of women [26]. In contrast, Kennedy et al. [27] and Sheu et al. [15] confirmed the existence of such a relationship only in the group of men. A study performed by Sheu et al. also showed that leptin levels are higher in men diagnosed with essential hypertension compared with those without hypertension. The relationship was not confirmed in similar groups of women [15]. The resulting differences in the tests performed may be due to the complex relationship between leptin and insulin. They may also be the result of analysing different ethnic groups and populations with different clinical characteristics $[15,26]$. Moreover, an elderly population participated in the study of Sheu et al. and most of the patients were taking antihypertensives [15]. Most authors suggest the need for extreme caution with mutual extrapolation of the results obtained in male and female populations as well as within the surveyed ethnic groups $[12,16]$.

\section{Conclusions}

1. Women with obesity and hypertension have higher levels of leptin than obese men with hypertension.

2. Reported correlations between serum leptin and blood pressure suggest that it is directly or indirectly involved in the pathophysiology of hypertension in obese individuals regardless of gender.

\section{References}

1. Lian Y., Tang Z., Xie Y. et al. Leptin receptor gene polymorphisms and risk of hypertension: a meta-analysis. Int. J. Clin. Exp. Med. 2015; 8: 14277-14282.

2. Agata J., Masuda A., Takada M. et al. wsp. High plasma immunoreactive leptin level in essential hypertension. Am. J. Hypertens. 1997; 10: 1171-1174.

3. Dutkiewicz-Rakowska M., Wocial B., Ignatowska-Świtalska H. et al. Czy istnieje współzależność między stężeniem leptyny, układem współczulnym i masą lewej komory serca u chorych z nadciśnieniem tętniczym pierwotnym w zależności od płci i wskaźnika masy ciała? Nadciśnienie Tętnicze 2002; 2: 91-97.

4. Masuo K., Mikami H., Ogihara T. et al. Sympathetic nerve hyperactivity precedes hyperinsulinemia and blood pressure elevation in a young, nonobese Japanese population. Am. J. Hypertens. 1997; 10: 77-83.

5. Suter P.M., Locher R., Häsler E. et al. Is there a role for ob gene product leptin in essential hypertension? Am. J. Hypertens. 1998; 11: 1305-1311.

6. Haynes W.G., Morgan D.A., Djalali A. et al. Interactions between the melanocortin system and leptin in control of sympathetic nerve traffic. Hypertension1999; 33: 542-547.

7. Haynes W.G., Morgan D.A., Walsh S.A. et al. Sympathetic activation to leptin is mediated by the hypothalamus. FASEB J. 1998; 12: 376.

8. Jackson E.K., Li P. Human leptin has natriuretic activity in the rat. Am. J. Physiol. 1997; 272: 333-338. 
9. Serradeil-Le Gal C., Raufarte D., Brassard G. et al. Characterization and location of leptin receptors in the rat. Fed. Eur. Biochem. Soc. Lett. 1977; 404: 185-191.

10. Sader S., Nian M., Liu P. Leptin: a novel link between obesity, diabetes, cardiovascular risk and ventricular hypertrophy. Circulation 2003; 108: 644-646.

11. Considine R.V., Sinha M.K., Herman M.L. et al. Serum immunoreactive - leptin concentrations in normal — weight and obese humans. N. Engl. J. Med. 1996; 334: 292-295.

12. Saad M.F., Damani S., Gingerich R.L. et al. Sexual dimorphism in plasma leptin concentration. J. Clin. Endocrinol. Metab. 1997; 82: 579-584.

13. Rosenbaum M., Nicolson M., Hirsch J. et al. Effects of gender, body composition, and menopause of plasma concentrations of leptin. J. Clin. Endocrinol. Metab. 1996; 81: 3424-3427.

14. Shimizu H., Shimomura Y., Nakanishi Y. et al. Estrogen increases in vivo leptin production in rats and human subjects. J. Endocrinol. 1997; 154: 285-292.

15. Sheu W.H.-H., Lee W.J., Chen Y.T. High plasma leptin concentrations in hypertensive men but not in hypertensive women. J. Hypertens. 1999; 17: 1288-1295.

16. Shorr U., Blanschke K., Turan S. et al. Relationship between angiotensinogen, leptin and blood pressure levels in young normotensive men. J. Hypertens. 1998; 16: 1475-1480.

17. Tykarski A., Narkiewicz K., Gaciong Z. et al. 2015 Guidelines for the management of hypertension. Arterial Hypertens. 2015; 19: 53-83.

18. Tykarski A., Narkiewicz K., Gaciong Z. et al. 2015 Guidelines for the management of hypertension. Part 8. Arterial Hypertens. 2015; 19: $153-173$.
19. Lönnqvist F., Arner P., Nordfors L. et al. Overexpression of the obese (ob) gene in adipose tissue of human obese subjects. Nat. Med. 1995; 1: 950-953.

20. Mannucci E., Ognibene A., Becorpi A. et al. Relationship between leptin and estrogenes in healthy women. Eur. J. Endocrinol. 1998; 139: 198-201.

21. Schwartz M.W., Woods S.C., Porte D.Jr et al. Central nervous system control of food intake. Nature 2000; 404: 661-671.

22. Hall J.E., Hildebrandt D.A., Kuo J. Obesity hypertension: role of leptin and sympathetic nervous system. Am. J. Hypertens. 2001; 14: 103-115.

23. Lembo G., Vecchione C., Fratta L. et al. Leptin induces direct vasodilatation through distinct endothelial mechanisms. Diabetes 2000; 49: 293-297.

24. Mark A.L., Carreia M.L.G., Rahmoui K. et al. Selective leptin resistance: a new concept in leptin physiology with cardiovascular implications. J. Hypertens. 2002; 20: 1245-1250.

25. Huby A.C., Otvos L., Belin deChantemele E.J. Leptin induces hypertension and endothelial dysfunction via aldosterone-dependent mechanisms in obese female mice. Hypertension 2016; 67: 1020-1028.

26. Carantoni M., Abbasi F., Azhar S., et al. Plasma leptin concentrations do not appear to decrease insulin-mediated glucose disposal or glucose-stimulated insulin secretion in women with normal glucose tolerance. Diabetes 1998; 47: 244-247.

27. Kennedy A., Gettys T.W., Watson P. et al. The metabolic significance of leptin in humans: gender based differences in relationship to adiposity, insulin sensitivity and energy expenditure. J. Clin. Endocrinol. Metabol. 1997; 82: 1293-1300. 